\title{
studia
}

\section{Problem odpowiedzialności w filozofii Levinasa}

Jak pisze Jacek Filek: „Współczesne filozofowanie nad człowiekiem i jego światem znajduje swoją kulminację w filozofii odpowiedzialności, gdzie odpowiedzialność uzyskuje rangę podstawowego pojęcia filozoficznego ${ }^{1 ”}$.

Jeśli można uzupełnić to spostrzeżenie własną refleksją: w dyskursie etycznym daje się przy tym zaobserwować swoisty zwrot od etyki czystych zasad do etyki odpowiedzialności. Sygnalizuje to na przykład Ryszard Wiśniewski, stwierdzając:

Współczesną etykę jako filozofię moralności interesuje już nie tyle kwestia posłuszeństwa normom czy strategia optymalizacji celów czy dóbr, ile problem odpowiedzialności i godności człowieka w relacji do drugiego człowieka i kształtowanie siebie samego w tym stosunku².

Jak wiadomo, refleksja nad istotą fenomenu odpowiedzialności w sposób wyjątkowo owocny podjęta została w XX wieku na gruncie fenomenologii przez Husserla i jego uczniów, a w ramach filozofii dialogu przez Bubera, Rosenzweiga i Grisebacha. Ważną rolę odegrała tu również twórczość Jean Paul Sartre’a, który rozciągnął pole rozważań nad odpowiedzialnością poza

\footnotetext{
${ }^{1}$ Filozofia odpowiedzialności XX wieku, red. J. Filek, Kraków 2004, s. 9.

${ }^{2}$ R. Wiśniewski, Problem samobójstwa moralnego, [w:] Koncepcje i problemy w filozofii zła, red. M. Jaranowski, R. Wiśniewski, Toruń 2009, s. 247.
} 
granice bytu ludzkiego. Człowiek, zwraca uwagę ten klasyk egzystencjalizmu, jest odpowiedzialny nie tylko za siebie, lecz również za wszystko, co się wokół niego dzieje ${ }^{3}$. Georg Picht pisał z kolei o odpowiedzialności dziejowej, a Hans Jonas rozróżnił odpowiedzialność naturalną i kontraktową. To tylko niektóre dwudziestowieczne koncepcje podejmujące interesujące nas zagadnienie.

Wśród tych pozostałych szczególną rolę odgrywa myśl Emmanuela Levinasa - filozofa, który, moim zdaniem, w dziejach myśli europejskiej kwestię odpowiedzialności człowieka doprowadził do najbardziej radykalnej formy.

Celem niniejszego artykułu będzie właśnie próba przedstawienia kategorii odpowiedzialności jako kluczowego pojęcia myśli Levinasa. Złożoność tej myśli, charakteryzująca się tendencją do ustawicznego wprowadzania zmian, stawiania dylematów i proponowania coraz to nowych rozwiązań uznanych za kluczowe, utrudnia odseparowanie samego zagadnienia odpowiedzialności od innych, równie ważnych problemów aksjologicznych o podobnym wydźwięku znaczeniowym.

Podczas swojej próby analizy za kluczowe uznaję pojęcia: mowy, podmiotowości i „oności” (nie jest to pomyłka ortograficzna, lecz własna propozycja Levinasa). Na drodze skrótowego siłą rzeczy opisu znaczenia tych pojęć (określanych tu specyficznie mianem figur) oraz zachodzących między nimi relacji, postaram się w miarę możliwości pokazać, jak Levinas stawia swej modelowej podmiotowości coraz radykalniejsze warunki, począwszy od konieczności „zajmowania się sobą" i „odpowiedzialności za własne istnienie”, aż do nieuchronnej odpowiedzialności za Innego związanej z koniecznością poświęcenia się. W celu zachowania porządku i chronologii toku wywodu spróbuję odwołać się do klasycznego schematu podziału filozofii Levinasa ${ }^{4}$. Postaram się też przedstawić wysubtelnienia i zmiany, odnoszące się do rozumienia interesującego nas pojęcia, jakie francuski filozof wprowadza w trakcie rozwoju swej doktryny.

W mojej próbie rekonstrukcji opieram się przede wszystkim na lekturze rozprawy Inaczej niż być lub ponad istotą, stanowiącej zwieńczenie późnego etapu twórczości myśliciela. Rozwija on w niej i radykalizuje swoje wcześniejsze poglądy, zwłaszcza w kwestii rozumienia pojęć: nieskończony, substytucja, odpowiedzialność i podmiotowość. W Inaczej niż być..., podjęta zostaje

\footnotetext{
${ }^{3}$ Victor Frankl wprowadzi, kluczowe wręcz dla terapii egzystencjalnej, pojęcie odpowiedzialności pozamoralnej.

${ }^{4}$ Mam na myśli podział zaproponowany przez Marka Jędraszewskiego w książce Wobec Innego. Relacje międzypodmiotowe w filozofii E. Levinasa. Jędraszewski dzieli myśl Levinasa na trzy etapy - ontologiczny, metafizyczny oraz etyczny.
} 
też próba odpowiedzi na pytanie, w jaki sposób podmiotowość otwiera się na inność i skąd wynika jej wezwanie do ofiary. Sam fakt związku podmiotowości z odpowiedzialnością nie wyczerpuje bowiem istoty interesującego nas zagadnienia. Levinas posuwa się dalej: odpowiedzialność uznaje za fundament ludzkiej podmiotowości.

\section{DLA SIEBIE}

W jednym ze swoich pierwszych dzieł, Czas i to, co inne, opisując problem relacji człowieka do bycia, Levinas nawiązuje do przemyśleń Heideggera. Za najważniejsze odkrycie niemieckiego myśliciela uznaje ujawnienie różnicy ontyczno-ontologicznej wyznaczonej przez pojęcia byt (Seiende) - bycie (Sein). „To Heideggerowskie rozróżnienie jest dla mnie najgłębszą rzeczą w Sein und Zeit. Ale u Heideggera jest rozróżnienie, lecz nie ma separacji. Istnienie zawsze jest ujmowane $\mathrm{w}$ istniejącym - i w odniesieniu do istniejącego, którym jest człowiek ${ }^{5}$ ".

Bez takiej separacji nie jest możliwe zachowanie inności bycia postulowanej przez Heideggera. Bycie jest zawsze związane z egzystencją, co znaczy, że przysługuje pewnemu komuś $(\text { Dasein })^{6}$, kto je posiada. Levinas stawia sobie za cel uchwycenie momentu wyłaniania się ludzkiej podmiotowości ${ }^{7} \mathrm{w}$ swej czystej formie, czyli po odseparowaniu jej od konkretnych przedmiotów przynależących do świata (Heideggerowskie Seiende). Podmiotowość musi jego zdaniem wiązać się z samym faktem bycia (Sein). Związek z byciem samym w sobie ujawniają takie fenomeny naszych wewnętrznych odczuć jak: znużenie, zmęczenie, wysiłek, lenistwo. Ich analizy Levinas prezentuje w rozprawie Istniejący $i$ istnienie ${ }^{8}$. Przykładowo: znużenie charakteryzuje się jego zdaniem tym, że dotyczy samego naszego istnienia, a nie jakiegoś wybranego aspektu naszego życia. Mówiąc ściślej: wynika ono z obowiązku mojego istnienia - ja jestem znużony samym sobą. Wymienione fenomeny odczuć wewnętrznych umożliwiają więc odsłonięcie istnienia samego, na podobnej zasadzie, na jakiej możliwe jest Heideggerowskie otwarcie się na bycie (Sein).

\footnotetext{
${ }^{5}$ E. Levinas, Czas i to co inne, przeł. J. Migasiński, Warszawa 1999, s. 27-28.

${ }^{6} \mathrm{~W}$ tak krótkim artykule nie da się podjąć problemu różnicy pojmowania problemu ontologicznej mojości u Heideggera i Levinasa.

${ }^{7}$ Oczywiście terminy „podmiot” - „przedmiot” nie występują u Heideggera. Występuje tu przeciwstawienie trójfazowe: Sein - Dasein - Seiende.

${ }^{8}$ E. Levinas, Istniejący i istnienie, przeł. J. Margański, Kraków 2006, s. 30-50.
} 
Sens pojęcia „bycie” oddaje Levinas poprzez wprowadzenie terminu il y a. Sformułowanie il y a oznacza jest się, lecz nie zawiera czasownika być. Il y a to bycie anonimowe, wykraczające ponad wszelką kategoryzację.

To wpisane w bycie, niepohamowane, anonimowe pożeranie osoby, ów pomnik w głębi samej nicości określimy terminem il y a. Albowiem il y a wykracza poza wewnętrzność i zewnętrzność. Nie pozwala nawet jednego od drugiego odróżnić. Anonimowy strumień bycia zalewa, zatapia każdy przedmiot, osobę lub rzecz?.

Il y a nie jest podmiotem ani przedmiotem, nie jest nicością ani bytem. Jest pełną pustką i bezsensownym czuwaniem, istnieniem bez wyjścia. Takie czyste istnienie il y a, kojarzone $\mathrm{z}$ fenomenem odczucia grozy jest czymś złym. ${ }^{10}$ Jego nieokreśloność skłania do ucieczki. Aby nie zostać przez owo anonimowe istnienie pochłoniętym, człowiek musi nieustannie dokonywać aktów utożsamiania. Utożsamienie zaś to zamknięcie się w sobie, zwinięcie się i stworzenie monady.

O ile jestem, jestem monadą. Jestem bez drzwi i okien właśnie przez istnienie, a nie dzięki jakiejkolwiek treści, która byłaby we mnie niekomunikowana. Jeśli jest niekomunikowalna, to dlatego, że jest zakorzeniona w moim byciu, które jest tym, co najbardziej prywatne we mnie ${ }^{11}$.

W ten sposób możliwa staje się ucieczka od bezosobowego istnienia, określonego przez takie pojęcia, jak: zdobycie świadomości, zwinięcie się, przyjęcie określonej pozycji. Zawieszenie il y a i pojawienie się bytującego, Levinas określił mianem hipostazy. Marek Jędraszewski wyjaśnia to następująco:

dzięki niej [hipostazie - M. Ch.] anonimowe bycie traci swój charakter groźby. Byt staje się panem bycia, swojego bycia. W zdarzeniu hipostazy realizuje się dzieło identyfikacji: zachodzi, w rzeczywistości, wyjście od siebie jak również powrót do siebie. Byt bierze na siebie swoje własne bycie, zamyka się w sobie ${ }^{12}$.

\footnotetext{
${ }^{9}$ Tamże, s. 90. W dziele tym Levinas w ciekawy sposób wyjaśnia i opisuje il y a, porównując ten stan do np. mroku, nocy, grozy.

${ }^{10}$ Levinas porównując byt do zła niejako przygotowuje grunt do swoich dalszych rozważań. Zło bycia skłania do ucieczki. W związku z tym sens istnienia podmiotowości ma wykraczać poza stosunek bycie-byt. Podmiotowość ma być ufundowana etycznie - celem jest inaczej niż być.

${ }^{11}$ E. Levinas, Czas i to, co inne, s. 24.

${ }^{12}$ M. Jędraszewski, Wobec Innego. Relacje międzypodmiotowe w filozofii Emmanuela Levinasa, Poznań 1990, s. 47-48. Hipostaza jest również wyjaśniona przez Jacka Migasińskiego w książ-
} 
Hipostaza to istnienie, które konstytuuje się jako ciało. W dziełach Istniejący $i$ istnienie oraz Czas $i$ to, co inne narodziny owej cielesnej hipostazy łączy Levinas ze zdobyciem świadomości ${ }^{13}$. Z kolei w Całości i nieskończoności opis ukonstytuowanej podmiotowości wzbogacony zostaje o fenomeny pracy i domostwa, symbolizujące życie ekonomiczne oraz rozkoszowanie się, którego treścią stają się żywioły. Nie wchodząc w szczegóły niezwykle interesujących analiz dotyczących pojedynczych fenomenów, przypomnijmy w dużym skrócie, jaki sens ma pojęcie „życie ekonomiczne”.

Podmiot poprzez pracę ustanawia swoje posiadanie, potrafi gromadzić dobra, będ ą c s obą - w swo i m egoizmie i panując nad swoją rzeczywistością. Dom jako miejsce, gdzie podmiot mieszka, przywodzi na myśl wycofanie się z anonimowego świata i ukonstytuowanie własnej tożsamości. Tu muszę zająć się sobą, co znaczy, że troszczę się tylko o siebie, bo w ten sposób podtrzymuję swoje własne istnienie. Podmiot jako pan swego bycia jest tu jeden, sam. Wypełnienie samym sobą ukazuje wówczas materialność jego istnienia. Świadomy własnej cielesności dąży do zaspokojenia swoich potrzeb materialnych.

Zagadnienie materialności zostaje opisane przez Levinasa w Czasie i to, co inne w następujący sposób:

Materialność nie jest wyrazem przypadkowego upadku ducha w grobowiec czy też więzienie ciała. Towarzyszy ona - w sposób konieczny - wyłonieniu się podmiotu w jego wolności istniejącego. Pojmowanie ciała w ten sposób, poczynając od materialności - jako konkretnego wydarzenia relacji między Mną a Sobością - to sprowadzenie go do rangi wydarzenia ontologicznego. [...] To cała materialność człowieka ${ }^{14}$.

Samotność człowieka nie wynika z faktu braku kogoś drugiego, lecz z tego, że podmiot jest zdeterminowany przez swoją materialność. W ten sposób „odmalowany” zostaje tu obraz człowieka szczęśliwego, rozkoszującego się własnym życiem: „życie jest życiem czymś, jest szczęściem. Życie to doznawanie i czucie. Żyć znaczy rozkoszować się"15.

ce W stronę metafizyki, Nowe tendencje metafizyczne w filozofii francuskiej połowy XX wieku, w której autor trafnie porównuje hipostazę do auto-ustalenia i samo-zakrzepnięcia.

${ }^{13}$ E. Levinas, Istniejacy $i$ istnienie, s. 75-77 oraz Czas i to, co inne s. 34-35.

${ }^{14}$ E. Levinas, Czas i to, co inne, s. 45.

${ }_{15}$ Tenże, Całość i Nieskończoność. Esej o zewnętrzności, przeł. M. Kowalska, Warszawa 2002, s. 124. 
W takiej perspektywie odpowiedzialność przybiera kształt odpowiedzialności za siebie i swoje istnienie. Celem staje się nieustanne utożsamianie z samym sobą, a ściślej ucieczka przed anonimowym il $y$ a. Jestem odpowiedzialny tylko za siebie, odpowiedzialność zaś może być tutaj pojmowana jako troska o swoje bycie: o to, aby być i aby być sobą.

\section{DLA INNEGO}

Materialna, samotna hipostaza nie stanowi sama przez się celu bycia człowiekiem. Celem tym jest otwarcie na inność i etyczne zobowiązanie. Należy przy tym pamiętać, że z kolei warunek otwarcia i rozmowy z Innym stanowi ukonstytuowanie się cielesnej i świadomej ludzkiej podmiotowości gotowej do spotkania. Powróćmy do przywołanego wcześniej fenomenu domu: dom to moje miejsce życia wyrwane $\mathrm{z}$ anonimowości świata, moje odseparowanie, zdolne zarazem do gościny, czyli do przyjęcia drugiego człowieka ${ }^{16}$. Oczywiście mogę też otworzyć swój dom przed Innym. Nawiązanie relacji z kimś radykalnie ${ }^{17}$ Innym, powoduje $z$ kolei zmianę ukierunkowania się mnie. Nie jestem już „dla siebie”, ale „dla drugiego”. Zamykam tym samym ontologiczny poziom konstytucji podmiotu i wkraczam na poziom właściwy - etyczny ${ }^{18}$, na którym Levinas przedkłada dobro nad bycie.

Jak zaznaczyłam, warunkiem zawiązania relacji z Drugim jest moja własna separacja, dzięki której zostaje zachowane wewnętrzne oddzielenie Ja-Ty. Inaczej nie nawiązywałabym relacji z Drugim, lecz z jakimś Pseudo-drugim, obiektem mojej wyobraźni. Pozostawałabym na poziomie ontologicznym, nie osiągając etycznego ${ }^{19}$. Dla Drugiego opuszczam swój własny byt - egoizm. Odchodzę od interesowności, a moje bycie pęka i rozpada się.

\footnotetext{
16 Tamże, s. 173-181.

${ }^{17}$ W filozofii słowo „radykalny” znaczy często „źródłowy”, od łacińskiego radix - korzeń. Ktoś radykalnie inny, to nie tylko i nie koniecznie ktoś zdecydowanie różniący się ode mnie przedmiotowo, lecz ktoś inny co do swej źródłowej istoty (u Heideggera i Jaspersa - egzystencji).

${ }^{18}$ Odpowiadałoby to Heideggerowskiej ontyczności współbycia tu oto (Mitdasein), choć Heidegger odżegnuje się od etyki.

${ }^{19}$ Epistemologicznie odpowiada on Heideggerowskiej ontyczności, ale Heidegger w Byciu i czasie odrzuca etyczność, przynajmniej na czas budowy ontologii egzystencjalnej. Z kolei dla Levinasa jest ona pojęciem podstawowym.
} 
Ja, które egzystuje, jest bowiem obciążone przez egzystujące, nad którymi dominuje. Obciążenie egzystencji to według mnie forma, jaką przybrała słynna heideggerowska troska. Stąd bierze się całkiem inny ruch: aby wyjść z tego il y a, nie należy ustanawiać siebie, lecz siebie obalać. Obalenie tej suwerenności jest dla ja społeczną relacją z drugim, relacją bez-inter-esowną ${ }^{20}$.

Moje pierwotne istnienie zamieniam na bezinteresowną odpowiedzialność za Drugiego. Wchodzę z Drugim w relację etyczną. Relacja ta, nie jest wynikiem potrzeby. Toż-Samy pragnie Innego. Owo pragnienie jest bliżej nieokreślone, oscyluje w nieznanym kierunku. Dlaczego? Jak wyjaśnia Levinas: „pragnienie metafizyczne zmierza do czegoś całkiem innego, do absolutnie innego [...] pragnienie metafizyczne nie szuka powrotu, bo jest pragnieniem krainy, w której wcale się nie urodziliśmy ${ }^{21}$ ".

W wyniku wcześniejszego odseparowania, które nie jest bynajmniej rozerwaniem pewnej całości tworzonej z Innym, pragnienie nie może być szukaniem czegoś utraconego, ale znanego. Różnicę między potrzebą, a pragnieniem wyjaśnia Józef Tischner:

potrzeba jest zawsze związana $\mathrm{z}$ jakimś nasycaniem się tym, ku czemu się zwraca. Potrzeba jest więc przywiązana do wspomnień [...] to, co upragnione, nie wypełnia pragnienia, ale je drąży. Dlatego upragnione jest nieuchwytne, niemożliwe do ogarnięcia pojęciem, absolutnie Inne ${ }^{22}$.

W swym dziele Filozofia dramatu, zafascynowany myślą Levinasa, Tischner porównuje pragnienie do otwarcia. ${ }^{23}$ Pragnienie powoduje wyjście z mojego własnego egoizmu. Mogę dzięki niemu doświadczyć Drugiego zderzam się z Twarzą - to właśnie ona, poprzez apel etyczny ${ }^{24}$, wzywa do odpowiedzialności. Twarz jest znaczeniem bez kontekstu, nie ma odniesienia, tła, jest naga. „Najpierw jest sama prawość twarzy, jej prawe i bezbronne wystawienie. Skóra twarzy pozostaje najbardziej nagą, najbardziej obnażoną.

${ }^{20}$ E. Levinas, Etyka i Nieskończony. Rozmowy z Philippem Nemo, przeł. B. Opolska-Kokoszka, Kraków 1982, s. 33.

${ }^{21}$ Tamże, s. 18-19.

22 J. Tischner, Myślenie według wartości, Kraków 2000, s. 171.

${ }^{23}$ J. Tischner, Filozofia dramatu, Kraków 2006, s. 29.

${ }^{24}$ Dochodzi tu do swoistego przełomu w pojmowaniu relacji pomiędzy etyką a estetyką, bo na przykład u Kanta, wartość estetyczna stanowić mogła tylko zastępczy, (pośredni) przedmiot etyki. 
Najbardziej nagą, chociaż nagością skromną. Również najbardziej obnażoną $25 "$.

Inny mówi do mnie. Ale dzięki samej mowie, ja i Inny nie tworzymy jeszcze żadnej wspólnoty. Levinas często podkreśla, że relacja Ja - Inny nie może mieć charakteru poznawczego, ponieważ poznanie jest zawłaszczeniem, czyli przemocą ${ }^{26}$. „Poznawanie jest rozwijaniem tożsamości” - czytamy w Całości i Nieskończoności $i^{27}$. Aby pokazać, w jakim sensie jest ono zawłaszczeniem, filozof stosuje ciekawy zabieg językowy. Odwołuje się do genealogii znaczenia czasownika comprendre wskazującej na słowa: poznać, pojąć, zrozumieć. Rdzeniem owego czasownika jest inny czasownik - prendre - wchłonąć, ująć, zawładnąć. ${ }^{28} \mathrm{~W}$ tej interpretacji zawłaszczenie jest niejako wpisane w poznanie, a ściślej: ukryte w nim. Poznanie jest więc formą przemocy. Aby relacja z Drugim mogła być od tej ostatniej wolna, potrzebna jest z kolei Mowa. Rozmowa utrzymuje bowiem dystans - jest sprawiedliwością. „Prawda pojawia się tam, gdzie byt oddzielony od innego bytu nie pogrąża się $\mathrm{w}$ nim, ale do niego mówi ${ }^{29 "}$.

To w mówieniu podmiotowość zostaje wezwana do odpowiedzialności (do zagadnienia Mowy nawiążę w dalszej części tekstu).

Przejdźmy teraz do kluczowego dla Levinasa problemu twarzy. Wiemy, że obnażona twarz Innego zaprasza do przemocy, a jednocześnie mówi „nie zabijaj. Twarz jest tym, co zabrania nam zabijać" ${ }^{30}$ - dlatego dostẹp do twarzy ma charakter etyczny. Słowa - „nie zabijaj” zmuszają mnie do podjęcia odpowiedzialności za Innego. Jest to nakaz absolutny. Zmuszona jestem wziąć na siebie odpowiedzialność, tym bardziej, że przede mną stoi twarz naga, najbardziej bezbronna $z$ bezbronnych - twarz obcego, wdowy, sieroty ${ }^{31}$. U Le-

\footnotetext{
${ }^{25}$ E. Levinas, Etyka i nieskończony. Rozmowy z Philippem Nemo, s. 49.

${ }^{26} \mathrm{~W}$ filozofii Indii ta sama idea wyrażona jest następująco: „Pragnienie prawdy jest najlepszym ze wszystkich pragnień, a jednak i ono jest jeszcze pragnieniem. Urzeczywistnienie wymaga odrzucenia wszystkich pragnień".

Nisargatta Maharaj, Nowe rozmowy z mędrcem, Bombaj 1976.

${ }^{27}$ E. Levinas, Całość i Nieskończoność, s. 124.

${ }^{28}$ Tenże, Totalité et infini. Essai sur l'extériorité, Paris 2008, s. 35-36. Zob. tenże, Całość i Nieskończoność, s. 71 (przypis).

${ }^{29}$ Tenże, Całość i Nieskończoność, s. 57.

${ }^{30}$ Tenże, Etyka i nieskończony. Rozmowy z Philippem Nemo, s. 49.

${ }^{31}$ Czytałam kiedyś, że pewien pilot bombowca bombardujący w czasie II wojny światowej miasta doznał szoku, gdy po raz pierwszy musiał zabić człowieka z bliska, z pistoletu.
} 
vinasa czytamy: „Inny, który panuje nade mną w swojej transcendencji, jest także obcym, wdową i sierotą - tym, wobec kogo mam obowiązki ${ }^{32}$ ".

Twarz Innego zobowiązuje. Pod jej wpływem ja zapominam o sobie. Pierwotnie rozkoszowałam się sobą, zamknięta w swoim bycie, w którym było mi dobrze. Teraz ów byt opuszczam.

Solipsystyczna dialektyka świadomości, zawsze podejrzewającej, że jest uwięziona w Toż-Samym, pęka. Fundująca rozmowę relacja etyczna nie jest bowiem odmianą świadomości, której promień wychodzi z Ja. Ja zostaje przez nią zakwestionowane. To zakwestionowanie przychodzi od Innego ${ }^{33}$.

Wezwanie Innego do odpowiedzialności tworzy wyłom w moim świecie. ఏa wymagam tylko od siebie, a Inny wobec mnie nie ma żadnym zobowiązań - jest moim mistrzem i nakazuje mi. Dlatego relacja Ja - Ty jest relacją asymetryczną.

Oto pełnia wymogu etycznego: rozpoznać $\mathrm{w}$ drugim nędzę i odpowiadać za niego, a jednocześnie być mu posłusznym, wsłuchiwać się w jego głos i odpowiadać na jego wezwanie. Żadnej symetryczności, żadnej równoważności - w postawie prawdziwie etycznej nie mogę oczekiwać od innego tego, czego powinienem wymagać od siebie ${ }^{34}$.

Moja odpowiedzialność nie wynika z przyjaźni czy bliskości, lecz zostaje mi narzucona. Ja służę Drugiemu (Levinas mówi tutaj o etyce opartej na fundamencie Twarzy wzywającej do całkowitej odpowiedzialności za Innego).

\section{ZA INNEGO}

W Całości i nieskończoności, podmiot wyłaniając się z il y a zdobywał świadomość, co oznaczało, że zwijał się i lokalizował. Rozkoszując się w swoim domostwie własnym egoizmem, był sobą, z sobą i dla siebie. Dopiero apel etyczny obecny w twarzy Innego wzywał go do odpowiedzialności, a tym samym do opuszczenia swojego świata i „bycia-dla”. W rozprawie Inaczej niż być lub ponad istotą stanowisko Levinasa ulega zmianie. Co prawda fi-

\footnotetext{
${ }^{32}$ E. Levinas, Całość i Nieskończoność, s. 256.

${ }^{33}$ Tamże, s. 229.

${ }^{34}$ J. Migasiński, $W$ stronę metafizyki. Nowe tendencje metafizyczne w filozofii francuskiej połowy XX wieku, Wrocław 1997, s. 304.
} 
lozof nigdy nie odżegnał się od treści Całości i nieskończoności, w późniejszym okresie swej twórczości twierdził jednak, że język, jakim się posługiwał w swoim głównym dziele był zbyt silnie zakotwiczony w ontologii. Wymóg wysubtelnienia języka starał się zrealizować w Inaczej niż być. Czytamy tu: „Esse jest interesse. Istota jest interesownością ${ }^{35}$ [...] Przejść od innego niż bycie, inaczej niż być. Nie być inaczej, ale inaczej niż być36". Aby móc mówić o podmiotowości, musimy wyjść poza ontologię ${ }^{37}$.

W kolejnym, trzecim, etapie twórczości filozofa odnajdujemy radykalną zmianę ukierunkowania się podmiotu - już bez kierowania się „ku sobie”, ani nawet „ku Innemu”, lecz przy przyjęciu postawy „za Innego”. Tak pojmowana odpowiedzialność stanowi tu o wzmiankowanej samej, czystej podmiotowości podmiotu. Relacja Ja - Inny nie jest chwilowo postrzegana jako część relacji Ja-świat. Człowiek w swej istocie staje się odpowiedzialnością samą w sobie. Być podmiotem, znaczy wówczas wyłącznie: być odpowiedzialnym za Drugiego. Przyjęcie odpowiedzialności jawi się zatem jako coś pra-pierwotnego, co poprzedza nawet samą możliwość doznawania.

Odpowiedzialność za innego nie może zaczynać się od mojego zaangażowania, od mojej decyzji. Nieograniczona odpowiedzialność, jakiej doświadczam, pochodzi spoza mojej wolności, z czegoś poprzedzającego wszelkie wspomnienie, z czegoś późniejszego niż wszelkie spełnienie, z czegoś, co nie jest obecne, co w pełnym, właściwym tego słowa znaczeniu jest nieźródłowe, an-archiczne, co leży poza lub ponad istotą ${ }^{38}$.

Istotę przyjęcia odpowiedzialności opisuje Levinas, odwołując się do bardzo ważnej w jego myśli kategorii bierności. „Odpowiedzialność jest biernością bardziej bierną niż jakakolwiek bierność, otwarciem się na innego bez woli takiego otwarcia, otwarciem się bez umiaru, otwarciem nad otwarciami, ekspresją, Mówieniem. ${ }^{39}$ Nic nie zrobiłem, ale zawsze byłem wzywany ${ }^{40}$.

Bierność prowadzi do ofiary z siebie za Innego, czyli, jak to określa Levinas, do substytucji. Substytucja zaś, czyli podstawienie samego siebie w miejsce

\footnotetext{
${ }^{35}$ E. Levinas, Inaczej niż być lub ponad istota, przeł. P. Mrówczyński, Warszawa 2000, s. 13.

36 Tamże, s. 12.

${ }^{37}$ Czyli poza płaszczyznę pytania jakie predykaty muszą przysługiwać czemuś, aby było tym oto czymś.

${ }^{38}$ E. Levinas, Inaczej niż być lub ponad istotą, s. 23.

${ }^{39}$ Ibidem, s. 31.

${ }^{40}$ Ibidem, s. 192.
} 
Drugiego, jest najbardziej podstawowym pojęciem określającym zewnętrzność świata. Bycie nią oznacza brak zainteresowania się samym sobą. Opisana relacja przypomina swoiste stanie się zakładnikiem - ja istnieję dla lub nawet za kogoś. „Zakładnik to ktoś, kto cierpi, jest prześladowany i umiera za (zamiast) kogoś. Zakładnik nie wybiera tego, za kogo umrze. Jest raczej z góry wybrany, naznaczony, pomazany. Jego odpowiedzialność jest wcześniejsza niż jego wybór ${ }^{41}$ ".

Przyjęcie wezwania do odpowiedzialności, a tym samym zrezygnowanie $\mathrm{z}$ własnego egoizmu być może więc w jedyny możliwy sposób naprawdę i do końca potwierdza mają podmiotowość. Zostaję wybrany do podtrzymywania Drugiego i nikt nie może mnie w tej odpowiedzialności zastąpić. „W bliskości inny jest moją obsesją, zgodnie $\mathrm{z}$ absolutną asymetrią znaczenia jeden-zadrugiego: ja zastępuję jego, podczas gdy nikt nie może zastąpić mnie ${ }^{42}$ ".

Nieusuwalność odpowiedzialności konstytuuje moją podmiotowość i moje prawdziwe ja - jedyne i niepowtarzalne. Odpowiedzialność nie wynika tu z przyjaźni, bliskości, lecz zostaje mi narzucona. Istnienie dla Drugiego nie jest moim wyborem, lecz dokonuje się jakby przed zaistnieniem mojej świadomości (nie jest to oczywiście tylko „przed” czasu chronologicznego). Zostałem przyporządkowany przez dobro jakiemuś innemu dobru i przeznaczony do ponoszenia odpowiedzialności.

Czyż Dobro nie wybrało podmiotu wyborem rozpoznawalnym w odpowiedzialności zakładnika, której podmiot się powierzył, przed którą nie może się ukryć, nie zakłamując siebie, i dzięki której stał się niezastępowalnym? Wyborem, któremu nie można przypisać - na sposób filozoficzny - innego znaczenia jak tylko znaczenie określone przez odpowiedzialność za bliźniego. Owa uprzedniość odpowiedzialności w stosunku do wolności oznaczałaby Dobroć Dobra: konieczność dla Dobra, by najpierw mnie wybrało, zanim ja zdołam je wybrać ${ }^{43}$.

Poprzez przypisaną mi odpowiedzialność, która poprzedza wszelką świadomość i wolność, dochodzi do indywidualizacji ludzkiej podmiotowości. Troszczę się o siebie po to, by być za Drugiego. Ponoszenie odpowiedzialności poprzedza zarówno relację przyjaźni, jak i sprawiedliwości. Jest więc podstawą wszelkich relacji międzyludzkich.

\footnotetext{
${ }^{41}$ Ibidem, s. 247.

${ }^{42}$ Ibidem, s, 264.

${ }^{43}$ J. Tischner, Spór o istnienie człowieka, Kraków 2001, s. 253.
} 
Tak radykalne ujęcie zagadnienia odpowiedzialności może budzić niepokój, tym bardziej, że Levinas w swym opisie pojęcia substytucji stosuje wyrażenia takie jak: opętanie, rozerwanie, ból, prześladowanie, ofiara. Sobość jest tu zaburzona, niespokojna, wezwana do odpowiedzialności, ale nie wie ona, skąd owo wezwanie pochodzi. „Jestem zobowiązany, choć zobowiązanie nie pochodzi ode mnie - jak gdyby rozkaz zakradł się do mojej świadomości niczym złodziej, wślizgnął się po kryjomu"44.

Levinas twierdzi, że ów rozkaz pochodzi spoza bycia - jest onością. $\mathrm{Na}$ temat oności czytamy zaś:

Jest to przykazanie władcze, ale pozbawione przymusu i dominacji, które nie pozwala mi ustanowić korelacji z jego źródłem, to znaczy złączyć się z nim w ramach jakiejś „struktury”, ale które sprawia, że mówienie, które do mnie przychodzi, jest moim własnym słowem. Autorytet [...] pozostaje [...] nie tylko poza wszelką intuicją, ale także poza wszelką tematyzacją, nawet symboliczną. Jest czystym śladem wpisanej we mnie „błąkającej się przyczyny”45.

Pod koniec Inaczej niż być Levinas wyjaśnia, że rozkaz jest śladem Boga. Bóg nie pojawia się jako bezpośredni rozmówca, wszystko wydarza się w oności:

Nieskończoność lub to, co transcendentne [...] pozostawia ślad swojego niemożliwego wcielenia oraz swojego bezmiaru w mojej bliskości z bliźnim [...] Ślad umykający, zacierający się [podkr. M. Ch.] i pojawiający się znowu, przypominający znak zapytania postawiony przed migotaniem dwuznaczności: nieskończona odpowiedzialność jednego za drugiego lub znaczenie Nieskończoności w odpowiedzialności. Dwuznaczność rozkazu nakazującego mi troskę o bliźniego, który jest moją obsesją oraz za którego i przed którym odpowiadam, wychodząc od mojego ja, przekształcając bycie w substytucję, w samą możliwość daru ${ }^{46}$.

W tym miejscu Levinas wprowadza pojęcie zacierającego się śladu. Najprawdopodobniej chce w ten sposób zaznaczyć, że człowiek nie jest w stanie dotrzeć do Boga bezpośrednio. W twarzy Drugiego zawsze odnajdujemy tylko jego umykający ślad. Oność oferuje zatem jakby okrężną drogę. Rozkaz

\footnotetext{
${ }^{44}$ E. Levinas, Inaczej niż być lub ponad istotą, s. 27.

${ }^{45}$ Tamże, s. 252.

46 Tamże, s. 270.
} 
nie wzywa do posłuszeństwa wobec Boga, ale do odpowiedzialności za Innego. Jedyny dostęp (o ile w tym przypadku w ogóle można mówić o dostępie) do Boga stanowi relacja Ja - Ty. Sama zaś oność przedstawiona jest jako ruch od Dobra w stronę Innego i z powrotem w stronę Dobra ${ }^{47}$.

Sądzę osobiście (przy pełnym szacunku dla innych sposobów interpretacji), że etyka Levinasa właśnie z powodu specyfiki zawartej w niej odpowiedzialności, pojmowanej jako naczelna zasada moralna, wiąże się jednak również z ontologicznym pytaniem o istnienie Boga. Posłuszeństwo Bogu wyraża się tu poprzez posługę wyświadczoną bliźniemu, co najdobitniej wyrażone zostało w Trudnej wolności słowami: Etyka jest optyka Boga ${ }^{48}$.

Powróćmy do sedna problemu odpowiedzialności. Nakazuje mi ona porzucić swój byt i oddać się obsesji Innego. Koncepcja Levinasa jest tu bardzo radykalna: bierny podmiot całkowicie poświęca się Drugiemu. Ów radykalizm znamionuje też bardzo w niej istotną kwestię Mowy. W Całości i Nieskończoności, Mowa potrzebna mi była do tego, by relacja nawiązana z Drugim pozostawała wolna od przemocy. W Inaczej niż być, podmiotowość ze swoją odpowiedzialnością staje się dla Levinasa samym mówieniem. Mowa okazuje się tu praźródłem bezinteresownego zwrócenia się do Drugiego. „Odpowiedzialność za innego człowieka jest Mówieniem poprzedzającym wszelkie Powiedziane ${ }^{49 \prime}$.

Mówienie staje się więc nie tylko komunikacją, lecz również wystawieniem się, a nawet stanięciem jeden-za-drugiego.

W ten sposób Levinas podkreśla, że podmiot w swej odpowiedzialności zostaje pozbawiony wszystkiego, co może stanowić jego własność. Dostrzegamy tu bezgraniczne oddanie się Drugiemu. „Mówienie odpowiedzialności jest jedynym przypadkiem, w którym jeden - który nie ukrywa się w sobie [...] wyzbywa się wszystkiego, stając się substytucją drugiego człowieka" ${ }^{50}$.

Dlaczego właśnie Mowa? Według Levinasa mowa jest wolna od przemocy. W relacji „ja otwieram się na Innego", nie dochodzi do narzucenia Innemu swej prawdy. Wszystko dokonuje się w obrębie aktu rozmowy. To mowa, a nie milczenie jest przeciwieństwem języka, bo język, jako system pojęć, oparty jest na konstrukcjach ontologicznych, a w efekcie rządzi nim przemoc. Mowa natomiast jest praźródłem języka.

\footnotetext{
${ }^{47}$ E. Levinas, O Bogu, który nawiedza myśl, tłum. M. Kowalska Kraków 1994, s. 130-131.

${ }^{48}$ Tenże, Trudna wolność. Eseje o judaizmie, tłum. A. Kuryś, Gdynia 1991, s. 167.

${ }^{49}$ Tenże, Inaczej niż być lub ponad istota, s. 77.

${ }^{50}$ Tamże, s. 233.
} 
Mówienie właśnie nie jest grą. Uprzednie wobec znaków, które łączy, uprzednie wobec systemów językowych i niuansów semantycznych - będąc przemową języków - jest bliskością jednego wobec drugiego, zobowiązaniem do zbliżenia, stawaniem jednego za drugiego, znaczącą siłą znaczenia [...] Źródłowe lub praźródłowe mówienie - mowa przed-mowy - zawiązuje intrygę odpowiedzialności ${ }^{51}$.

Marek Jędraszewski słusznie zauważył, że filozofia Levinasa jest „filozofią w drodze”. Jego myśl ewoluuje. Widzimy tu zmiany zachodzące w znaczeniu pojęć. Ponadto sam język, w miarę powstawania kolejnych dzieł, również ulega wysubtelnieniu. Myślę jednak, że najgłębsza ewolucja dokonała się w tym wypadku w sposobie pojmowania samej idei odpowiedzialności. Zaczęła się od sposobu rozumienia odpowiedzialności za siebie, a skończyła na pojęciu odpowiedzialności za Drugiego polegającej na poświęceniu się mnie. Odpowiedzialność jest niewątpliwie naczelną ideą etyki Levinasa. Poprzez wprowadzenie pojęcia „powołanie do odpowiedzialności” w rdzeń naszej podmiotowości, nasze dotychczasowe bycie sobą właściwie zostaje rozbite. Odpowiedzialność jest mi narzucona, ja zaś całkowicie „wystawiam się” Innemu. Szaleństwo odpowiedzialności każe mi porzucić swój świat - Drugi staje się moją obsesją. Moje całkowite poświęcenie staje się działaniem moralnie słusznym.

Wezwanie Levinasa cechuje niespotykany wcześniej radykalizm etyczny. Zrozumiałabym kogoś, kto dopatrywałby się tu masochistycznego okrucieństwa, ale nie podzielałabym jego zdania. Bo „zysk” ma być dla mnie wielki: określenie własnej podmiotowości. Zdaniem francuskiego myśliciela moje prawo do bycia musi być usprawiedliwione. Staje się to możliwe tylko w chwili przyjęcia zasady odpowiedzialności jako zasady poświęcenia się drugiemu człowiekowi. Tylko „odpowiedzialność zakładnika” daje mi prawo do bycia i usprawiedliwia moje bycie. A to usprawiedliwienie staje się zarazem określeniem:

odpowiedzialność jest tym, co wyłącznie spada na mnie i czego jako człowiek nie mogę odrzucić. To brzemię jest najwyższą godnością tego, co jedyne. Niezastąpionym ,ja" jestem tylko o tyle, o ile jestem odpowiedzialny. Mogę zastąpić wszystkich, ale nikt nie może zastąpić mnie. Taka jest moja niezbywalna tożsamość podmiotu ${ }^{52}$.

\footnotetext{
${ }^{51}$ Tamże, s. 15.

${ }^{52}$ E. Levinas, Etyka i nieskończony. Rozmowy z Philippem Nemo, s. 57.
} 


\section{Abstract \\ The issue of responsibility in Levinas' philosophy}

The aim of the article is the attempt of presenting the category of responsibility as a key notion in Emmanuel Levinas' philosophy. The complexity of the Frenchman's thoughts, introducing changes in strands of his philosophy makes it difficult to separate the issue of responsibility from other equally important notions that are closely related to the matter in which I am interested. Throughout the analysis of responsibility I mention the issue of Speech, Face, subjectivity and substitution. On the basis of the classical division scheme of Levinas' philosophy I try to demonstrate refinements and changes that the French philosopher introduces in the understanding of responsibility, starting from the responsibility for our own existence and ending on the responsibility for the Other related to the need of self-sacrifice. 